\title{
OPTIMASI SINTESIS ASAM LEMAK ETANOLAMIDA BERBASIS MINYAK KETAPANG MENGGUNAKAN RESPONSE SURFACE METHODOLOGY
}

\section{OPTIMIZATION SYNTHESIS OF FATTY ETHANOLAMIDE ACID BASED OF KETAPANG KARNEL OIL USING RESPONSE SURFACE METHODOLOGY}

\author{
Lilik Indriani, Erin Ryantin Gunawan*, dan Dedy Suhendra \\ Program Studi Kimia FMIPA Universitas Mataram, Mataram, Indonesia \\ *Email: erinryantin@unram.ac.id
}

Diterima: 8 Desember 2020. Disetujui: 11 Februari 2021. Dipublikasikan: 3 Maret 2021

\begin{abstract}
Abstrak: Telah dilakukan optimasi sintesis asam lemak etanolamida berbasis minyak ketapang (Terminalia catappa L) menggunakan Response Surface Methodology (RSM). Asam lemak etanolamida adalah surfaktan yang banyak dibutuhkan pada industri farmasi. Sintesis asam lemak etanolamida dilakukan dengan mereaksikan minyak ketapang dan etanolamina sebagai substrat menggunakan katalis Lipozyme TL.IM. Penelitian ini bertujuan untuk mengamati interaksi antar variabel yang dapat mempengaruhi kondisi optimum dan hasil reaksi. Beberapa variabel yang dimaksud yaitu waktu reaksi, suhu reaksi, molar rasio substrat dan jumlah enzim. Metode RSM yang digunakan terdapat dalam perangkat lunak Design Expert v.7. Hasil penelitian menunjukkan model untuk mendapatkan kondisi yang optimal adalah model quadratic ( $p$-value 0,0048/signifikan), lack of fit ( $p$-value 0,3827 /non signifikan) dan nilai $R$-squared sebesar 0,7953 . Kondisi optimum yang dihasilkan yaitu waktu reaksi $1,50 \mathrm{jam}$, suhu reaksi $38,10{ }^{\circ} \mathrm{C}$, molar ratio minyak : etanolamina $(1: 20,52) \mathrm{g} / \mathrm{mol}$ dan jumlah enzim $0,16 \mathrm{~g}$ dengan prediksi dan aktual persen hasil asam lemak etanolamida secara berturut-turut sebesar 60,02 dan $64,00 \%$.
\end{abstract}

Kata Kunci: Asam Lemak Etanolamida, RSM, Minyak Ketapang, Design Expert v.7, Lypozime TL IM.

\begin{abstract}
Optimization of fatty ethanolamide acid have been synthesized based on ketapang karnel oil (Terminalia catappa L.) using Response Surface Methodology (RSM). Fatty ethanolamide acid is a surfactant that is widely needed in the pharmaceutical industry. The fatty ethanolamide acid synthesis was carried out by reacting ketapang karnel oil and ethanolamine as a substrate using Lipozyme TL.IM catalyst. This study aims to observe the interactions between variables that can affect the optimum conditions and reaction results. Some of the variables referred to are reaction time, reaction temperature, the molar ratio of the substrate, and the number of enzymes. The RSM method used is contained in the Design Expert v.7 software. The results showed that the model to obtain optimal conditions is a quadratic model ( $\mathrm{p}$-value 0.0048 / significant), lack of fit ( $\mathrm{p}$-value 0.3827 / nonsignificant), and an R-squared value of 0.7953 . The resulting optimum conditions were reaction time of 1.50 hours, reaction temperature of $38.10^{\circ} \mathrm{C}$, the molar ratio of oil: ethanolamine $(1: 20.52) \mathrm{g} / \mathrm{mol}$, and the amount of enzyme $0.16 \mathrm{~g}$ with the predicted and actual percent yield of fatty ethanolamide acid respectively amounted to 60.02 and $64.00 \%$.
\end{abstract}

Keywords: Fatty Ethanolamide Acid, RSM, Ketapang Karnel Oil, Design Expert v.7, Lypozime TL IM.

\section{PENDAHULUAN}

Asam lemak etanolamida merupakan senyawa amida yang banyak digunakan dalam industri kimia, kosmetik, maupun otomotif. Senyawa ini memiliki gugus hidrofilik dan hidrofobik. Oleh karena itu, asam lemak etanolamida dapat berperan sebagai surfaktan [1]. Surfaktan dapat ditemukan sebagai bahan pembersih rumah tangga, kertas, tinta, agrokimia, dan perawatan pribadi atau obat-obatan [2]. Kebutuhan surfaktan di Indonesia semakin meningkat seiring dengan perkembangan industri deterjen [3]. Kebutuhan surfaktan di Indonesia sekitar 95.000 ton per tahun, sedangkan kapasitas produksi dalam negeri sekitar 55.000 ton per tahun. Ini berarti bahwa Indonesia masih mengimpor sekitar 44.500 ton surfaktan per tahun [4].
Umumnya surfaktan yang digunakan diproduksi dari minyak bumi yang bisa berdampak pada lingkungan dan kesehatan [5]. Surfaktan yang banyak disintesis dari minyak bumi yaitu surfaktan Linier Alkil Benzen Sulfonat (LAS) yang tidak ramah lingkungan [6].

Seiring perkembangan teknologi, sintesis surfaktan berbasis tumbuhan mulai dikembangkan, salah satunya yaitu surfaktan yang diproduksi dari minyak-minyak nabati, seperti minyak kelapa [7] dan minyak kelapa sawit [6]. Minyak kelapa dan minyak kelapa sawit merupakan minyak nabati yang banyak digunakan pada industri pangan. Oleh karena itu, jika surfaktan diproduksi dari minyak nabati pangan maka akan menyebabkan adanya kompetisi penggunaan bahan baku. Berdasarkan hal tersebut, maka dibutuhkan bahan baku yang 
merupakan minyak nabati non pangan untuk produksi surfaktan asam lemak etanolamida. Umumnya, reaksi yang digunakan untuk menghasilkan asam lemak etanolamida yaitu reaksi amidasi dengan mereaksikan asam lemak, metil ester atau trigliserida dengan etanolamina [8]. Selain itu, asam lemak etanolamida banyak diproduksi menggunakan katalis kimia melalui reaksi Schotten Baumann antara asam lemak atau metil ester asam lemak dengan monoetanolamina atau dietanolamina dengan menggunakan katalis seng oksida $(\mathrm{ZnO})$ pada suhu $150{ }^{\circ} \mathrm{C}$ selama 6-12 jam [9] Asam lemak etanolamida juga dapat diproduksi secara enzimatik dengan transesterifikasi yang dikatalisis oleh lipase. Salah satu minyak nabati non pangan yang berpotensi sebagai sumber asam lemak etanolamida adalah minyak inti buah ketapang [10].

Ketapang merupakan pohon pantai dengan daerah penyebarannya cukup luas. Tanaman ini berasal dari daerah tropis di India, kemudian menyebar ke Asia Tenggara, Australia Utara dan Polynesia di Samudra Pasifik [11]. Sayangnya pemanfaatan buah ketapang di Indonesia belum optimal. Menurut [12] dan [13] bahwa komposisi asam lemak dari minyak inti buah ketapang terdiri dari asam lemak tak jenuh yaitu oleat (32-38 \%), linoleat (12-21\%) serta asam lemak jenuh yaitu stearat (3-4 \%), asam palmitat (25-31 \%). Kandungan asam lemak menurut penelitian yang dilakukan oleh Suhendra dkk. (2010) minyak ketapang memiliki kandungan asam oleat (39-55 $\%)$, palmitat $(32-35 \%)$, linoleat $(7-21 \%)$ dan stearat $(2-5 \%)$. Biji ketapang memiliki kandungan minyak yang cukup tinggi, yaitu sebesar 40-57\% [14.]

Sintesis asam lemak etanolamida dari inti buah ketapang sudah dilakukan oleh [9] melalui reaksi enzimatis menggunakan katalis Lypozime TL IM dengan kondisi optimum yaitu waktu reaksi 2 jam, konsentrasi substrat (etanolamina) $25 \mathrm{mmol}$, jumlah enzim $0,20 \mathrm{~g}$ dan suhu reaksi $40{ }^{\circ} \mathrm{C}$. Penelitian tersebut masih menggunakan metode one variable at time dalam menentukan kondisi optimum sintesis dan mendapatkan persen hasil sebesar 60,07 \%. Metode one variable at time merupakan suatu metode yang digunakan untuk menentukan kondisi optimum dari suatu proses dengan memvariasikan satu variabel saja, sedangkan variabel yang lain dibuat konstan. Cara ini belum efektif untuk melihat interaksi antara variabel yang satu dengan variabel yang lain. Apabila teknik ini digunakan untu menentukan keadaan optimum dari empat faktor (waktu reaksi, temperatur, massa enzim dan konsentrasi substrat) maka akan menghasilkan jumlah eksperimen yang banyak yaitu 150 eksperimen dan 450 eksperimen jika dilakukan 3 kali pengulangan, sehingga kurang efektif dari segi waktu dan biaya. Selain itu, persen hasil yang didapatkan menggunakan metode one variable at time dirasa kurang maksimum, oleh karena itu perlu dilakukan optimasi reaksi sehingga diharapkan dapat meningkatkan persen hasil yang didapatkan.

Oleh karena itu, diperlukan metode lain untuk mengkaji lebih dari dua variabel secara simultan. Metode yang paling tepat untuk hal ini adalah menggunakan Response Surface Methodology (RSM). Alternatif ini lebih menguntungkan dari segi waktu dan biaya dibandingkan dengan menggunakan bahan kimia yang banyak, karena dapat dioptimasi terlebih dahulu dengan software sebelum melakukan penelitian lebih lanjut di laboratorium, sehingga dapat mengurangi jumlah eksperimen yang akan dilakukan. Selain itu, diharapkan dengan metode ini, persen hasil yang didapatkan jauh lebih tinggi dibandingkan dengan menggunakan metode one variabel at time.

Adapun RSM merupakan sekumpulan teknik matematika dan statistik yang berguna menganalisis permasalahan dimana beberapa variabel independen mempengaruhi variabel respon dan tujuan akhirnya adalah untuk mengoptimalkan respon [15]. RSM yang terdiri dari Central Composite Rotatable Design (CCRD) lima tingkat, empat faktor digunakan dalam penelitian ini untuk mengevaluasi efek interaktif dan untuk mendapatkan kondisi optimal untuk sintesis enzimatis asam lemak etanolamida dari minyak inti buah ketapang. Metode ini telah banyak digunakan untuk menentukan kondisi optimum dari suatu proses diantaranya yaitu pada penelitian [16].

Metode ini bertujuan untuk mengoptimalkan hasil reaksi dengan mengamati berbagai kondisi yang dipengaruhi oleh beberapa variabel yaitu waktu reaksi, molar rasio, jumlah enzim dan suhu reaksi terhadap persen hasil yang didapatkan. Adapun pada penelitian [17] yang menggunakan metode one variable at time mendapatkan persen hasil sebesar 59,7 \% sedangkan penelitian [18] yang menggunakan RSM mendapatkan persen hasil sebesar $65,7 \%$. Hal ini dapat menunjukkan bahwa optimasi menggunakan RSM diharapkan memiliki persen hasil yang lebih tinggi dibandingkan sintesis secara enzimatis menggunakan one variable at time.

Berdasarkan uraian di atas dapat dilakukan sintesis asam lemak etanolamida dari minyak inti buah ketapang dengan melakukan optimasi terlebih dahulu menggunakan RSM, dan akan dilihat interaksi antar variabel sehinga didapatkan kondisi optimum reaksi serta diharapkan mendapatkan persen hasil yang tinggi.

\section{METODE PENELITIAN \\ Alat dan Bahan}

Alat-alat yang digunakan pada penelitian ini adalah alat gelas yang biasa digunakan di 
laboratorium, desikator, elektraktor, kromatografi lapis tipis (KLT), KVC, pH meter (PH-009(I)A), termometer, penangas air, oven, statif, klem, vacum filtration, rotary eveporator (B-ONE RE-1000VN), magnetic stirer, timbangan analitik (DC-600A), Chamber, stirrer waterbath (Biosan WB-4MS) dan FTIR (Perkin Elmer Spektrum Two, AS), Labu kjeldahl dan pengolahan data menggunakan Software Design Expert v.7.

Bahan-bahan yang digunakan pada penelitian ini adalah bahan yang berderajat p.a kecuali yang disebutkan demikian, ketapang, $n$ heksan (Merck, Darmstadt, Jerman), etanolamina (Sigma-Aldrich $\geq 98 \%$, USA), $\mathrm{HCl}$ (Merck, Jerman, etanol (Merck, Jerman), indikator pp, Lypozime TL IM (Novozymes LA330045, Denmark), $\mathrm{Na}_{2} \mathrm{SO}_{4}$ anhidrat (Merck, Jerman), $\mathrm{NaOH}$ (Merck, Jerman), $\mathrm{Na}_{2} \mathrm{~S}_{2} \mathrm{O}_{3}$ (Merck, Jerman), Virgin Coconut Oil (VCO) (Al Amin, Indonesia), palmitoyleilethanolamide (Mindhack), $\mathrm{CCl}_{4}$ (Merck, Jerman), KI (Merck, Jerman), $\mathrm{H}_{2} \mathrm{SO}_{4}$ (Merck, Jerman), NaOH (Merck, Jerman).

\section{Ekstraksi dan Pemurnian Minyak Ketapang}

Inti ketapang dihaluskan dan ditimbang sebanyak $60 \mathrm{~g}$ dan disokletasi selama 6 jam dengan $250 \mathrm{~mL}$ pelarut $n$-heksana. Proses pemurnian minyak inti buah ketapang yaitu menggunakan kromatografi kolom dengan metode [19] dengan modifikasi. Kromatografi kolom dipreparasi basah dengan $50 \mathrm{~g}$ minyak ketapang dicampurkan dengan silika gel kemudian dimasukkan ke dalam kolom. Eluen dimasukkan ke dalam kolom melalui dinding kolom secara perlahan. Hasil pemisahan kemudian diuapkan untuk menghilangkan pelarut $n$-heksana dengan rotary evaporator pada suhu $40^{\circ} \mathrm{C}$ dengan kecepatan $100 \mathrm{rpm}$. Persentase kadar minyak dapat dihitung melalui persamaan berikut

$$
\text { Kadar Minyak }=\frac{\text { Berat Minyak }}{\text { Berat Inti Buah Ketapang }} \times 100
$$

\section{Desain Eksperimen}

Rancangan percobaan yang digunakan yaitu Cenral Composite Rotatable Design (CCRD) dengan rancangan percobaan orde 2 yang terdiri dari 4 faktor 5 level. Faktor dan level yang digunakan yaitu berdasarkan pada penelitian [18] yang menggunakan metode one variable at time dengan 4 faktor (suhu reaksi, waktu reaksi, konsentrasi substrat dan jumlah enzim). Terdapat 6 center point dan 8 axial point. Oleh karena itu, jumlah percobaan (N) yaitu 30 percobaan Rancangan percobaan menggunakan Design Expert v.7 dapat dihitung jumlah percobaannya seperti pada persamaan berikut:

$$
\mathrm{N}=2^{\mathrm{k}}+C P+A P
$$

Keterangan:

$\begin{array}{ll}\mathrm{N} & =\text { Total percobaan } \\ \mathrm{k} & =\text { Jumlah faktor } \\ \mathrm{CP} & =\text { Center point }\end{array}$

AP = Axial point

\section{Sintesis Asam Lemak Etanolamida}

Sintesis asam lemak etanolamida dilakukan secara enzimatis dari asam lemak minyak inti buah ketapang. Metode sintesis yang digunakan yaitu metode yang sudah dikembangkan oleh [20] dengan modifikasi dan penyesuaian dengan kondisi dari masing-masing reaksi yang dilakukan. Reaksi secara umum yaitu campuran reaksi yang terdiri dari trigliserida minyak ketapang, pelarut $n$-heksana, Lypozime TL IM dan etanolamina sebagai substrat yang sudah dinetralkan dengan $\mathrm{HCl} \quad 6 \quad \mathrm{M}$ pada $\mathrm{pH} \quad 7$ dimasukkan dan direaksikan sesuai dengan kondisi reaksi yang diperoleh dari aplikasi Design Expert v.7 pada desain eksperimen. Persen hasil yang didapatkan dapat dihitung seperti pada persamaan berikut:

$$
\text { Persen Hasil }=\frac{\text { Massa Alkiletanolamida }}{\text { Massa Minyak }} \times 100
$$

\section{Analisis Statistik dan Validasi Model}

Hasil percobaan 30 kombinasi sintesis asam lemak etanolamida dianalisis menggunakan Design Expert v.7. Analisis statistika yang dilakukan berupa ANOVA untuk mengetahui kecocokan model dan interaksi antar variabel terhadap respon. Model yang disarankan program dapat berupa model Linear, 2FI, Quadatic dan Cubic. Adapun signifikansi model pada orde 2 dilihat dari uji kesesuaian model (Lack of Fit) dan uji parameter regresi. Model yang baik dapat dilihat dari nilai $\mathrm{R}^{2}$.

Berdasarkan analisis statistika yang dilakukan, akan disajikan persen hasil prediksi dari sintesis asam lemak etanolamida dan interaksi antar variabel terhadap respon. Interaksi antar variabel terhadap respon disajikan dalam bentuk contour plot dan response surface plot.

\section{Optimasi Reaksi}

Solusi optimum reaksi sintesis asam lemak etanolamida diberikan setelah analisis statistika dilakukan dan interaksi antar variabel terhadap respon diketahui. Solusi kondisi optimum yang memilik respon (persen hasil) prediksi tinggi dilakukan pengujian kembali di laboratorium, sehingga diketahui persen hasil aktual dari reaksi optimum sintesis asam lemak etanolamida.

\section{HASIL DAN PEMBAHASAN \\ Ekstraksi dan Pemurnian Minyak Ketapang}

Kadar minyak ketapang yang diperoleh dari proses ekstraksi dengan 3 kali pengulangan yaitu sebesar 52,23\%. Persentasi kadar minyak yang diperoleh lebih tinggi dari hasil penelitian [14] dengan metode yang sama 


\section{Desain Eksperimen}

Percobaan yang dilakukan pada penelitian ini menggunakan CCRD yang dapat membantu mengetahui efek model yang digunakan. Masingmasing bervariasi pada 4 faktor 5 level. Empat faktor yang dimaksud yaitu variabel yang digunakan yaitu empat variabel yang terdiri dari suhu reaksi, waktu reaksi, konsentrasi substrat dan jumlah enzim. Lima level yang dimaksud yaitu kondisi pengujian parameter reaksi yaitu diambil pada titik 0 (titik pusat), satu tingkat $(+1$ dan -1$)$ serta dua tingkat (+2 dan -2$)$. Nilai tengah atau titik pusat dari parameter reaksi diambil berdasarkan studi sebelumnya yaitu penelitian [9]. Berdasarkan rancangan percobaan 4 faktor 5 level yang dilakukan, selanjutnya disajikan 30 kombinasi sintesis asam lemak etanolamida yang diuji coba di laboratorium. Persen hasil prediksi adalah persen hasil yang diberikan oleh software. Persen hasil prediksi muncul ketika persen hasil aktual di-input ke dalam aplikasi Design Expert v.7 kemudian dilakukan analisis statistika. Persen hasil aktual dan prediksi dapat dilihat pada Tabel 1.

Tabel 1. Persen Hasil Aktual dan Prediksi Asam Lemak Etanolamida

\begin{tabular}{|c|c|c|c|c|c|c|}
\hline \multirow[b]{2}{*}{ Std } & \multirow{2}{*}{$\begin{array}{c}\text { A } \\
\text { Waktu } \\
\text { (Jam) }\end{array}$} & \multirow{2}{*}{$\begin{array}{c}\text { B } \\
\text { Suhu } \\
\left({ }^{\circ} \mathrm{C}\right)\end{array}$} & \multirow{2}{*}{$\begin{array}{c}\mathrm{C} \\
\begin{array}{c}\text { Etanolamina } \\
(\mathrm{mmol})\end{array}\end{array}$} & \multirow{2}{*}{ 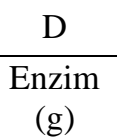 } & \multicolumn{2}{|c|}{ Hasil (\%) } \\
\hline & & & & & Aktual & Prediksi \\
\hline 1 & 1,00 & 30,00 & 20,00 & 0,15 & 69,00 & 62,46 \\
\hline 2 & 3,00 & 30,00 & 20,00 & 0,15 & 60,00 & 56,96 \\
\hline 3 & 1,00 & 50,00 & 20,00 & 0,15 & 47,00 & 47,29 \\
\hline 4 & 3,00 & 50,00 & 20,00 & 0,15 & 65,00 & 65,79 \\
\hline 5 & 1,00 & 30,00 & 30,00 & 0,15 & 70,00 & 65,29 \\
\hline 6 & 3,00 & 30,00 & 30,00 & 0,15 & 49,00 & 47,29 \\
\hline 7 & 1,00 & 50,00 & 30,00 & 0,15 & 52,00 & 53,13 \\
\hline 8 & 3,00 & 50,00 & 30,00 & 0,15 & 63,00 & 59,13 \\
\hline 9 & 1,00 & 30,00 & 20,00 & 0,25 & 57,00 & 60,29 \\
\hline 10 & 3,00 & 30,00 & 20,00 & 0,25 & 53,00 & 48,29 \\
\hline 11 & 1,00 & 50,00 & 20,00 & 0,25 & 46,00 & 44,12 \\
\hline 12 & 3,00 & 50,00 & 20,00 & 0,25 & 52,00 & 56,13 \\
\hline 13 & 1,00 & 30,00 & 30,00 & 0,25 & 63,00 & 58,63 \\
\hline 14 & 3,00 & 30,00 & 30,00 & 0,25 & 35,00 & 34,13 \\
\hline 15 & 1,00 & 50,00 & 30,00 & 0,25 & 43,00 & 45,46 \\
\hline 16 & 3,00 & 50,00 & 30,00 & 0,25 & 42,00 & 44,96 \\
\hline 17 & 0,00 & 40,00 & 25,00 & 0,20 & 45,00 & 48,08 \\
\hline 18 & 4,00 & 40,00 & 25,00 & 0,20 & 41,00 & 42,08 \\
\hline 19 & 2,00 & 20,00 & 25,00 & 0,20 & 43,00 & 52,25 \\
\hline 20 & 2,00 & 60,00 & 25,00 & 0,20 & 53,00 & 47,92 \\
\hline 21 & 2,00 & 40,00 & 15,00 & 0,20 & 69,00 & 70,75 \\
\hline 22 & 2,00 & 40,00 & 35,00 & 0,20 & 60,00 & 62,42 \\
\hline 23 & 2,00 & 40,00 & 25,00 & 0,10 & 52,00 & 58,75 \\
\hline 24 & 2,00 & 40,00 & 25,00 & 0,30 & 45,00 & 42,42 \\
\hline 25 & 2,00 & 40,00 & 25,00 & 0,20 & 56,00 & 53,33 \\
\hline 26 & 2,00 & 40,00 & 25,00 & 0,20 & 51,00 & 53,33 \\
\hline 27 & 2,00 & 40,00 & 25,00 & 0,20 & 55,00 & 53,33 \\
\hline 28 & 2,00 & 40,00 & 25,00 & 0,20 & 54,00 & 53,33 \\
\hline 29 & 2,00 & 40,00 & 25,00 & 0,20 & 51,00 & 53,33 \\
\hline 30 & 2,00 & 40,00 & 25,00 & 0,20 & 65,00 & 53,33 \\
\hline
\end{tabular}

\section{Sintesis Asam Lemak Etanolamida}

Adapun persamaan reaksi pembentukan asam lemak etanolamida dari reaksi antara trigliserida ketapang dengan etanolamina dan dikatalisis dengan Lypozime TL IM dapat dilihat pada Gambar 1. Hasil sintesis asam lemak etanolamida yang terbentuk harus dimurnikan terlebih dahulu, karena dalam reaksi tidak hanya asam lemak etanolamida yang terbentuk tetapi masih ada juga produk sampingan seperti gliserol dan bahan-bahan lain yang mungkin tersisa atau belum bereaksi. 


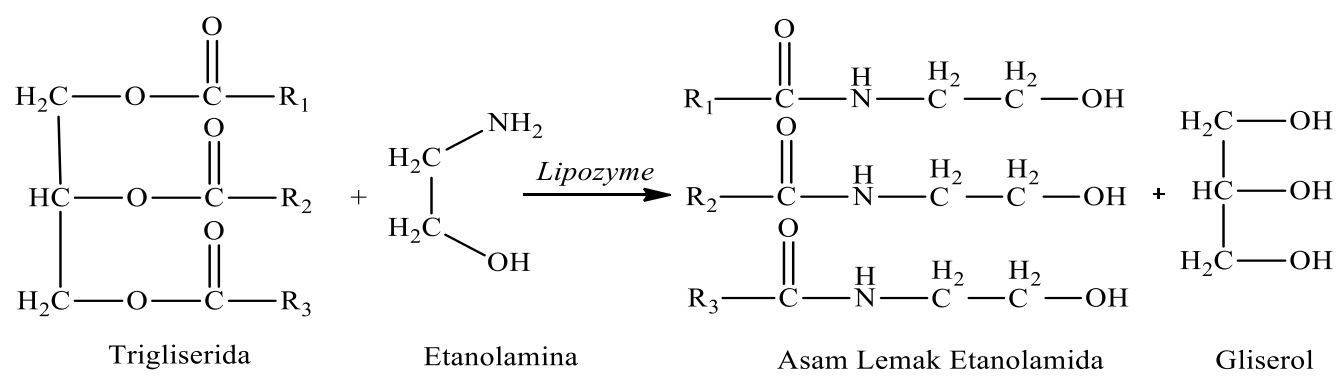

Gambar 1. Reaksi sintesis asam lemak etanolamida

\section{Analisis Statistika ANOVA dan Validasi Model} $<0,05$.

Parameter pengaruh signifikan dari suatu faktor adalah besarnya nilai probabilitas $p$-value yaitu $p$-value

Tabel 2. ANOVA Model Quadratic Sintesis Asam Lemak Etanolamida

\begin{tabular}{lrrrrr}
\hline \multicolumn{5}{c}{ ANOVA for Quadratic Model (Suggested) } \\
\hline Model & Sum of Squares & $d f$ & Mean Square & F-value & p-value \\
A-Waktu & 1938,55 & 14 & 138,47 & 4,16 & $0,0048^{\mathrm{a}}$ \\
B-Suhu & 54,00 & 1 & 54,00 & 1,62 & $0,2220^{\mathrm{b}}$ \\
C-Etanolamina & 28,17 & 1 & 28,17 & 0,85 & $0,3720^{\mathrm{b}}$ \\
D-Enzim & 104,17 & 1 & 104,17 & 3,13 & $0,0971^{\mathrm{b}}$ \\
AB & 400,17 & 1 & 400,17 & 12,03 & $0,0034^{\mathrm{a}}$ \\
AC & 576,00 & 1 & 576,00 & 17,32 & $0.0008^{\mathrm{a}}$ \\
AD & 156,25 & 1 & 156,25 & 4,70 & $0,0467^{\mathrm{b}}$ \\
BC & 42,25 & 1 & 42,25 & 1,27 & $0,2774^{\mathrm{b}}$ \\
BD & 9,00 & 1 & 9,00 & 0,27 & $0,6105^{\mathrm{b}}$ \\
CD & 1,00 & 1 & 1,00 & $0 ., 30$ & $0,8647^{\mathrm{b}}$ \\
A $^{2}$ & 20,25 & 1 & 20,25 & 0,61 & $0,4474^{\mathrm{b}}$ \\
$\mathrm{B}^{2}$ & 180,11 & 1 & 180,11 & 5,41 & $0,0344^{\mathrm{a}}$ \\
$\mathrm{C}^{2}$ & 47,25 & 1 & 47,25 & 1,42 & $0,2518^{\mathrm{b}}$ \\
$\mathrm{D}^{2}$ & 216,96 & 1 & 216,96 & 6,52 & $0,0220^{\mathrm{a}}$ \\
Residual & 38,68 & 1 & 38,68 & 1,16 & $0,2979^{\mathrm{b}}$ \\
Lack of Fit & 498,92 & 15 & 33,26 & & \\
Pure Error & 365,58 & 10 & 36,56 & 1,37 & $0,3827^{\mathrm{b}}$ \\
Car Total & 133,33 & 5 & 26,67 &, & \\
\hline Signikan & 2437,47 & 29 & & & \\
\hline
\end{tabular}

${ }^{\text {aS }}$ Signifikan, p-value $<0,05$

bTidak signifikan, p-value $>0,05$

Model yang terdapat pada Tabel 2 memiliki nilai $p$-value sebesar 0,0048 , sehingga model dianggap signifikan karena $p$-value $<0,05$. Berdasarkan pada Tabel 4.6, A menunjukkan variabel waktu, B menunjukkan variabel suhu, C menunjukkan variabel etanolamina dan D menunjukkan variabel enzim. Jika dilihat dari tabel ANOVA, yang memiliki kriteria parameter atau signifikan terhadap respon adalah nilai enzim (D) serta interaksi antara waktu dan suhu (AB). Hal ini menunjukkan bahwa parameter $\mathrm{D}$ dan $\mathrm{AB}$ memiliki pengaruh yang tinggi terhadap respon dan model yang digunakan. Hal lain juga menunjukkan bahwa, nilai $\mathrm{A}^{2}$ dan $\mathrm{C}^{2}$ juga memiliki nilai yang signifikan terhadap respon. Hal ini menunjukkan bahwa peningkatan penambahan 2 kali variabel A (waktu reaksi) ataupun variabel C (Etanolamina) dapat mempengaruhi respon dengan baik. Dilihat pada Tabel 4.7 bahwa nilai lack of fit sebesar 0,3227 (tidak signifikan). Hal ini menunjukkan bahwa model regresi cocok.

Berdasarkan model dan analisis ANOVA yang dilakukan diperoleh persamaan statistika pada sintesis asam lemak etanolamida ini adalah:

Yield $(\%)=55,33-1,50 \mathrm{~A}-1,08 \mathrm{~B}-2,08 \mathrm{C}-$ $4,08 \mathrm{D}+6,00 \mathrm{AB}-3,12 \mathrm{AC}-$ $1,62 \mathrm{AD}+0,75 \mathrm{BC}-0,25 \mathrm{BD}-$ $1,12 \mathrm{CD}-2,65 \mathrm{~A}^{2}-1,31 \mathrm{~B}^{2}+2,81 \mathrm{C}^{2}$ $-1,19 \mathrm{D}^{2}$

Keterangan:

$\begin{array}{ll}\mathrm{A}=\text { Waktu } & \mathrm{B}=\text { Suhu } \\ \mathrm{C}=\text { Etanolamina } & \mathrm{D}=\text { Enzim }\end{array}$ 


\section{Analisis Regresi}

Nilai koefisien determinasi $\left(\mathrm{R}^{2}\right)$ untuk mengetahui apakah model yang diperoleh sudah sesuai dengan data, nilai $\mathrm{R}^{2}$ yang kecil berarti memiliki kemampuan variabel-variabel bebas dalam menjelaskan variabel-variabel terikat cukup terbatas [21].

Tabel 3. Analisis Regresi

\begin{tabular}{ccc}
\hline Factor & Coefficient Estimate & p-value \\
\hline Intersep & 55,33 & $0,0048^{\mathrm{a}}$ \\
A & $-1,50$ & $0,2220^{\mathrm{b}}$ \\
B & $-1,08$ & $0,3720^{\mathrm{b}}$ \\
C & $-2,08$ & $0,0971^{\mathrm{b}}$ \\
D & $-4,08$ & $0,0034^{\mathrm{a}}$ \\
AB & 6,00 & $0,0008^{\mathrm{a}}$ \\
AC & $-3,12$ & $0,0467^{\mathrm{b}}$ \\
AD & $-1,62$ & $0,2774^{\mathrm{b}}$ \\
BC & 0,75 & $0,6105^{\mathrm{b}}$ \\
BD & $-0,25$ & $0,8647^{\mathrm{b}}$ \\
CD & $-1,12$ & $0,4474^{\mathrm{b}}$ \\
A $^{2}$ & $-2,56$ & $0,0344^{\mathrm{a}}$ \\
$\mathrm{B}^{2}$ & $-1,31$ & $0,2518^{\mathrm{b}}$ \\
C $^{2}$ & 8,1 & $0,0220^{\mathrm{a}}$ \\
$\mathrm{D}^{2}$ & $-1,19$ & $0,2979^{\mathrm{b}}$ \\
\hline
\end{tabular}

${ }^{\text {aSignifikan jika p-value }<0,05}$

${ }^{\mathrm{b}}$ Tidak signifikan jika p-value $>0,05$

Tabel 4. Nilai Keakuratan Model

\begin{tabular}{lrlr}
\hline \multicolumn{4}{c}{ Fit Statistics } \\
\hline Std. Dev. & 5,77 & $R^{2}$ & 0,7953 \\
Mean & 53,53 & Adjusted $R^{2}$ & 0,6043 \\
C.V. $\%$ & 10,77 & Predicted $R^{2}$ & 0,0573 \\
& 2297,76 & Adeq Precision & 8,961 \\
\hline
\end{tabular}

$\begin{array}{cccc}\text { Berdasarkan Tabel } 4 & \text { diperoleh nilai } \\ \text { koefisien determinasi } \quad \mathrm{R}^{2}= & 0,7953 & \text { yang }\end{array}$ menunjukkan bahwa 79,53\% variabel pada sintesis asam lemak etanolamida dipengaruhi oleh variabel independen, dan 20,47 \% dari semua variabel yang tidak dapat dijelaskan oleh model. [22] menjelaskan bahwa nilai $\mathrm{R}^{2}$ cukup mendekati nilai 1 mengindikasikan derajat korelasi yang cukup tinggi antara observasi dan nilai prediksi. Nilai standar deviasi yang rendah sebesar 5,77 menggambarkan keakuratan model yang dipakai. Hubungan nilai Adjusted $\mathrm{R}^{2}$ sebesar 0,6043 mengoreksi nilai $\mathrm{R}^{2}$, dimana nilai Adjusted $\mathrm{R}^{2}$ bisa jadi lebih kecil dari nilai $\mathrm{R}^{2}$. Nilai C.V. \% (15,61 $\%)$ menggambarkan tingkat residu antara nilai aktual dan nilai prediksi dari sintesis asam lemak etanolamida.

\section{Interaksi Antar Variabel}

a. Interaksi Waktu dan Temperatur

Berdasarkan Gambar 2 terlihat interaksi antara waktu dan temperatur terhadap persen hasil yang diperoleh. Terlihat bahwa persen hasil asam lemak etanolamida maksimum pada suhu $30,10^{\circ} \mathrm{C}$ dengan waktu reaksi 1,16 jam. Hal ini dikarenakan pembentukan asam lemak etanolamida optimum pada waktu 1-2 jam [10]. Sedangkan pada suhu di atas $30,10^{\circ} \mathrm{C}$ dan waktu reaksi di atas 2 jam terjadi penurunan produk secara signifikan. Hal ini disebabkan karena semakin tinggi suhu, laju pergerakan setiap molekul akan semakin cepat, sehingga frekuensi tumbukan antar molekul akan meningkat dan reaksi menjadi semakin cepat [23]. Namun penambahan suhu harus disesuaikan dengan keadaan reaksi dan jenis reaktan. 

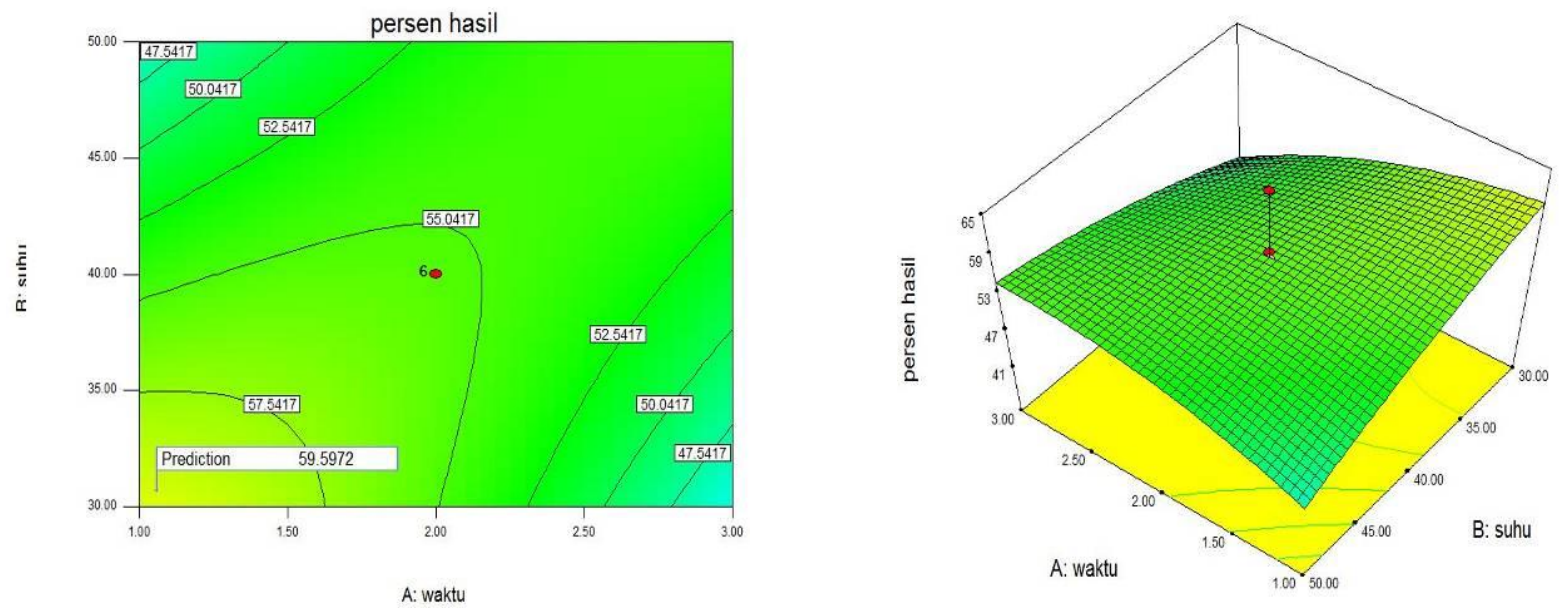

Gambar 2. Contour Plot dan Response Surface Plot Interaksi Waktu dan Temperatur

b. Interaksi Waktu dan Substrat (Etanolamina)

Berdasarkan pada Gambar 3 terlihat interaksi antara waktu dan substrat terhadap persen hasil yang diperoleh. Terlihat bahwa persen hasil asam lemak etanolamida maksimum pada waktu 2,5 jam dengan konsentrasi etanolamina sebesar 20,10 mmol. Akan tetapi setelah jumlah substrat lebih dari 20,10 mmol dan waktu reaksi lebih dari 2,5 jam, pembentukan asam lemak etanolamida kembali menurun. Hal ini berkaitan dengan teori kinetika enzim (Michaelis-Manten) bahwa semakin besar konsentrasi substrat, maka kecepatan reaksi enzimatik akan semakin besar hingga tercapai titik

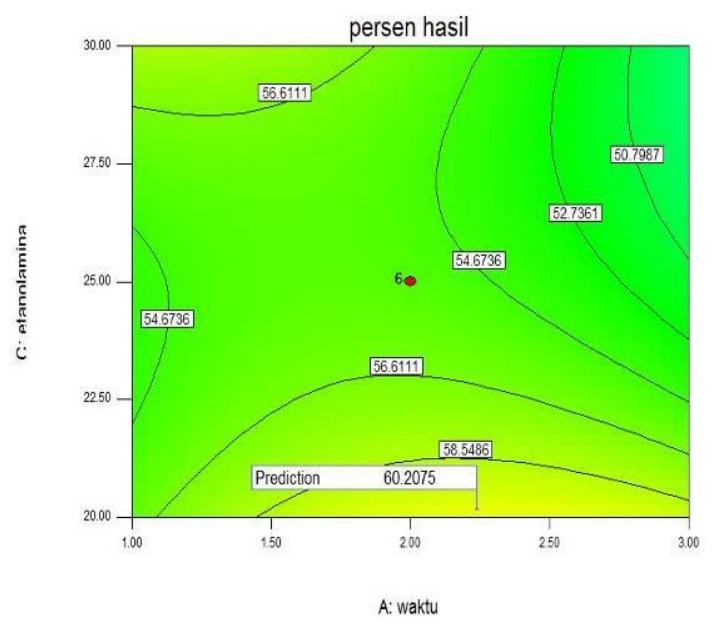

batas. Setelah titik batas terlampaui, kecepatan reaksi akan meningkat sedikit dengan bertambahnya konsentrasi substrat, tetapi tidak mencapai titik maksimum karena enzim menjadi jenuh oleh substratnya. Menurut [20], ketika konsentrasi substrat terlalu tinggi dapat menaikkan viskositas larutan sehingga interaksi antara reaktan menjadi tidak efektif dan dapat menghambat reaksi. Selain itu, hal tersebut juga dapat disebabkan karena reaksi pembentukan asam lemak etanolamida telah mencapai kesetimbangan (equilibrum) [24] pada waktu 2,5 jam.

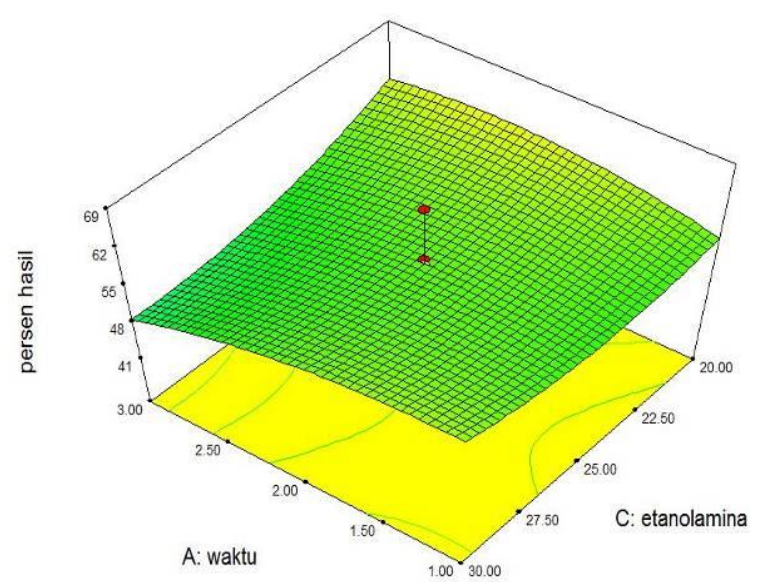

Gambar 3. Contour Plot dan Response Surface Plot Interaksi Waktu dan (Etanolamina)

c. Interaksi Waktu dan Enzim

Berdasarkan pada Gambar 4. Terlihat bahwa persen hasil asam lemak etanolamida maksimum pada waktu reaksi 2 jam dengan jumlah enzim yaitu $0,16 \mathrm{~g}$. Persen hasil asam lemak etanolamida maksimum pada waktu reaksi 2 jam ini disebabkan karena semakin tinggi jumlah enzim yang digunakan, maka kecepatan reaksi akan semakin meningkat yang menyebabkan titik optimum akan semakin cepat tercapai. Penambahan jumlah enzim, maka reaksi akan lebih cepat dan maksimal. Namun ini akan berhenti pada saat waktu optimum telah tercapai [25]. 

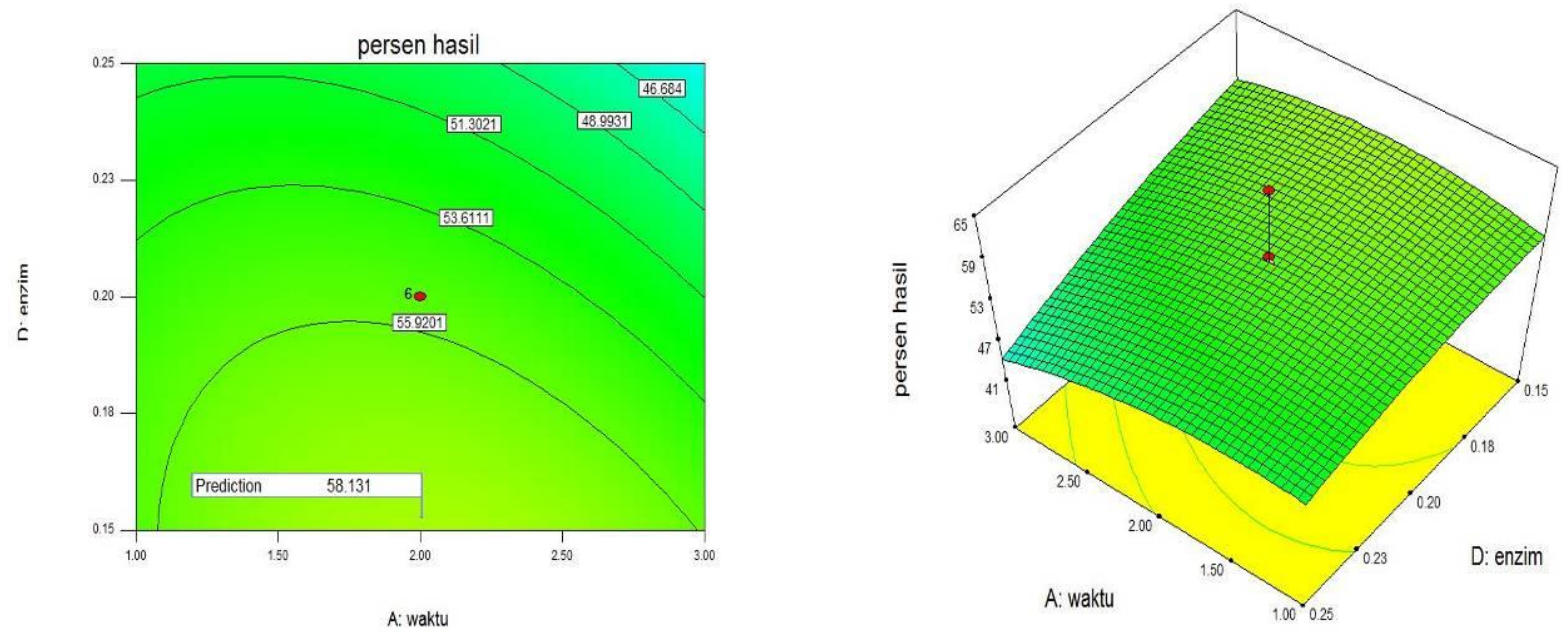

Gambar 4. Contour Plot dan Response Surface Plot Interaksi Waktu dan Enzim

d. Interaksi Suhu dan Substrat (Etanolamina)

Berdasarkan Contour plot dan response surface plot interaksi suhu dan etanolamina terlihat bahwa persen hasil asam lemak etanolamida maksimum pada suhu $36^{\circ} \mathrm{C}$ dengan substrat 20,10 mmol. Hal ini terjadi karena pada suhu yang lebih tinggi reaksi akan berlangsung lebih cepat karena kelarutan substrat meningkat dan tumbukan antar partikel semakin besar. Sedangkan pada suhu di atas $36^{\circ} \mathrm{C}$ terlihat penurunan produk, karena melebihi suhu optimum. Persen hasil asam lemak etanolamida tidak mengalami peningkatan di atas suhu $36^{\circ} \mathrm{C}$ dengan konsentrasi substrat lebih dari 20,10 mmol. Menurut [26], penambahan jumlah substrat secara berlebih dan setelah mencapai titik maksimum mengakibatkan penurunan jumlah produk yang dihasilkan [27].


Gambar 5. Contour plot dan response surface plot interaksi suhu dan etanolamina

e. Interaksi Suhu dan Enzim

Berdasarkan pada Gambar 6 terlihat Contour dan response surface plot interaksi antara suhu dan enzim terhadap persen hasil yang diperoleh. Terlihat bahwa persen hasil asam lemak etanolamida maksimum pada suhu $40^{\circ} \mathrm{C}$ dengan jumlah enzim $0,16 \mathrm{~g}$. Persen hasil asam lemak etanolamida maksimum pada suhu $40^{\circ} \mathrm{C}$ karena sebagian enzim memiliki suhu optimal pada suhu $30-40^{\circ} \mathrm{C}$ [28], ketika temperatur bergerak naik di atas $40^{\circ} \mathrm{C}$, maka akan berpengaruh pada kinerja enzim karena enzim mengalami denaturasi dan mematikan aktivitas katalisnya, sehingga akan menurunkan persen hasil yang diperoleh [29]. Persen hasil asam lemak etanolamida meningkat pada jumlah enzim $0,16 \mathrm{~g}$ disebabkan karena enzim merupakan katalis yang dapat mempercepat laju reaksi, sehingga jika digunakan enzim yang cukup maka reaksi akan berjalan cepat dan produk yang dihasilkan meningkat tetapi tidak melebihi batas optimum kerja enzim. 

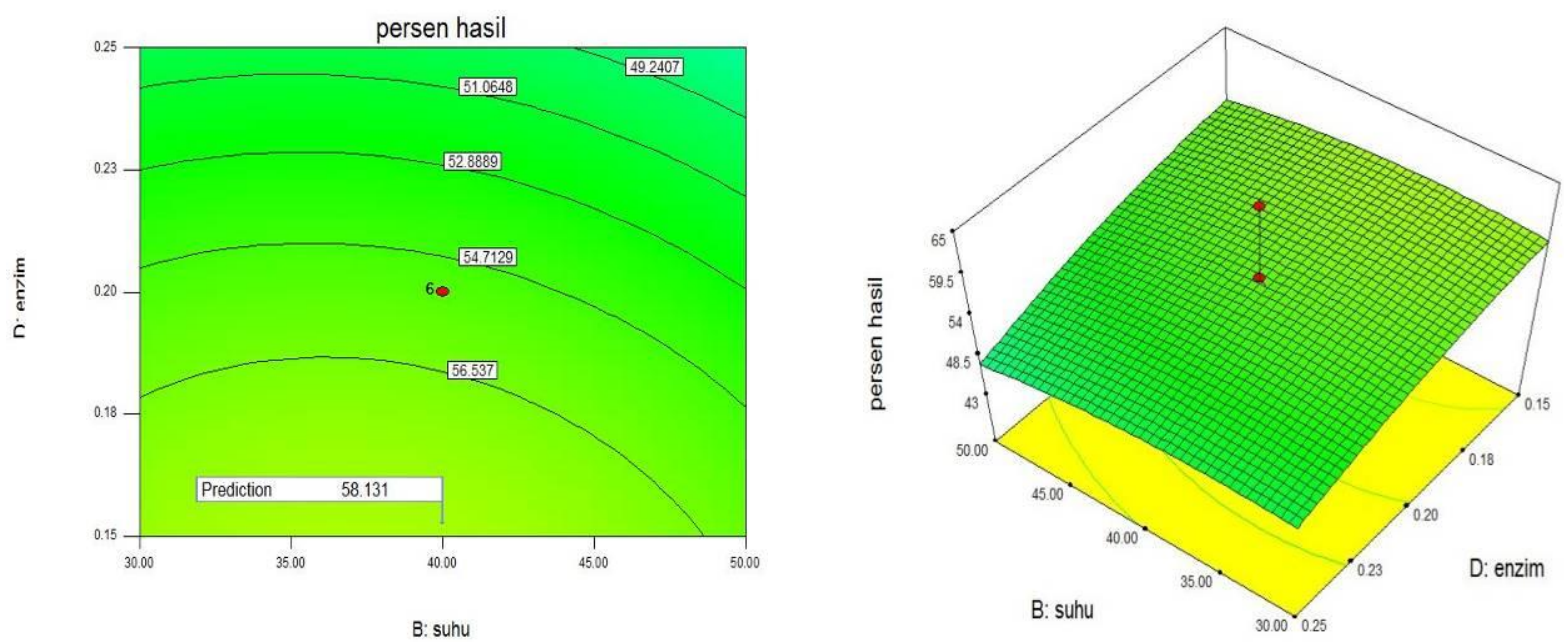

Gambar 6. Contour Plot dan Response Surface Plot Interaksi Suhu dan Enzim
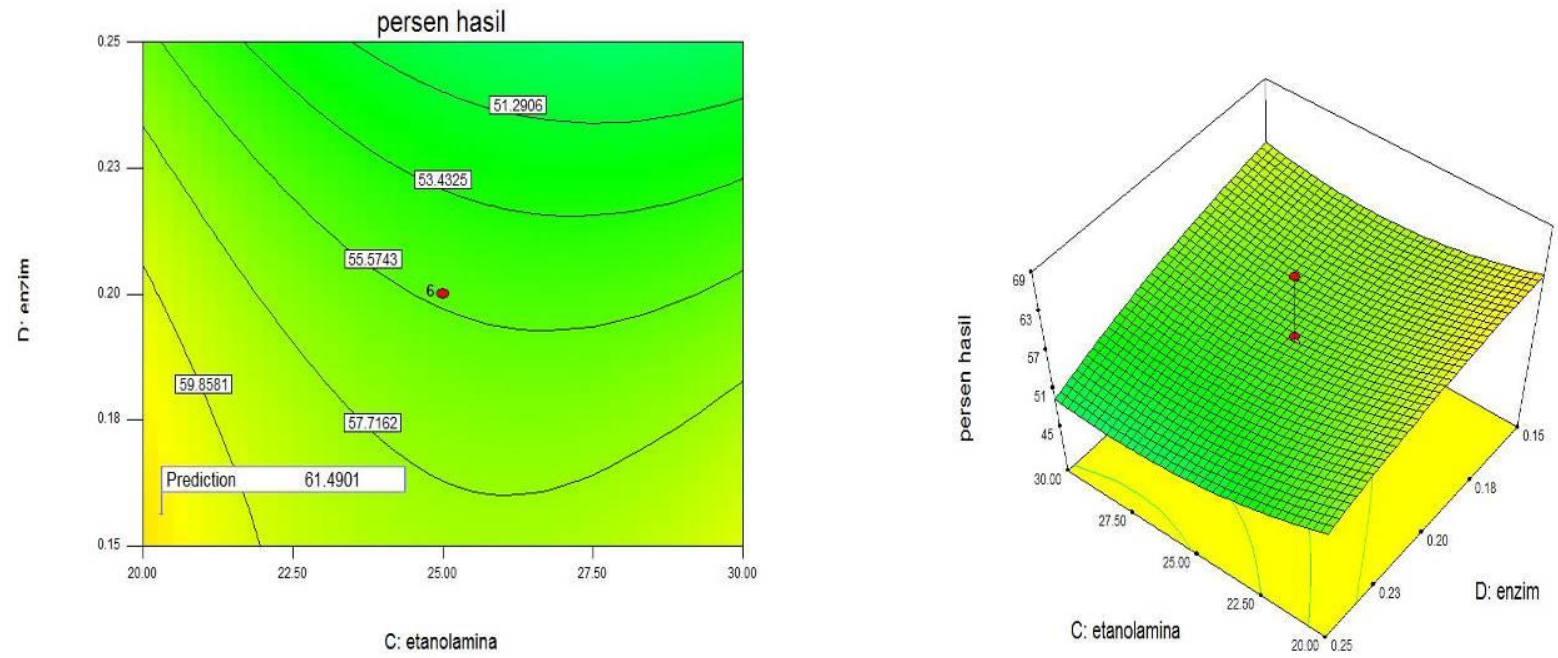

Gambar 7. Contour dan Response Surface Plot Interaksi Substrat dan Enzim

f. Interaksi Substrat (Etanolamina) dan Enzim

Berdasarkan pada Gambar 7 terlihat interaksi antara substrat (etanolamina) dan enzim terhadap persen hasil yang diperoleh. Persen hasil asam lemak etanolamida maksimum pada konsentrasi etanolamina 20,10 mmol dengan jumlah enzim $0,16 \mathrm{~g}$. Hal ini disebabkan karena semakin tinggi konsentrasi substrat, maka semakin banyak pula jumlah molekul substrat yang bersaing untuk menempel pada sisi aktif permukaan enzim [10]. Akan tetapi, pada konsentrasi substrat di atas 20,10 mmol tidak terjadi peningkatan persen hasil asam lemak etanolamida, hal ini disebabkan karena jumlah enzim tidak mampu menyaingi jumlah substrat yang bertambah dan tidak akan meningkatkan persen hasil secara signifikan [30]. Jika adanya penambahan jumlah enzim, maka enzim dapat mengkatalisis substrat lebih cepat dan maksimal. Namun ini akan berhenti pada saat waktu optimum tercapai [25].

Persen hasil asam lemak etanolamida semakin menurun di atas konsentrasi substrat 20,10 mmol dengan jumlah enzim lebih dari $0,16 \mathrm{~g}$. Rendahnya produk yang dihasilkan ini disebabkan oleh penghentian reaksi ke arah produk dikarenakan terbatasnya jumlah substrat yang dapat diubah oleh enzim lipase menjadi produk, sehingga peningkatan konsentrasi enzim yang tidak disertai dengan jumlah substrat yang tidak memadai maka tidak akan meningkatkan jumlah produk [25].

\section{Optimasi Reaksi}

Berdasarkan hasil optimasi dengan RSM pada Desain Expert v.7 melalui persamaan orde 2 diperoleh solusi optimasi dengan kombinasi dan prediksi persen hasil seperti yang terlihat pada Tabel 5. 
Tabel 5. Kondisi Optimum Sintesis Asam lemak Etanolamida

\begin{tabular}{cccccc}
\hline Percobaan & $\begin{array}{c}\text { Waktu } \\
(\mathrm{Jam})\end{array}$ & $\begin{array}{c}\text { Suhu } \\
\left({ }^{\circ} \mathrm{C}\right)\end{array}$ & $\begin{array}{c}\text { Etanolamina } \\
(\mathrm{mmol})\end{array}$ & $\begin{array}{c}\text { Enzim } \\
(\mathrm{g})\end{array}$ & Hasil Prediksi $(\%)$ \\
\hline 1 & 1,50 & 38,10 & 20,52 & 0,16 & 60,02 \\
2 & 1,50 & 32,26 & 20,96 & 0,22 & 59,75 \\
3 & 2,72 & 37,29 & 21,27 & 0,16 & 59,46 \\
4 & 2,21 & 44,01 & 23,33 & 0,16 & 58,57 \\
5 & 2,72 & 46,12 & 24,77 & 0,16 & 58,23 \\
\hline
\end{tabular}

Berdasarkan pada Tabel 5 dilakukan percobaan di laboratorium yaitu percobaan 1 untuk kondisi optimum sintesis dan didapatkan persen hasil yaitu sebesar 64,00 \%. Hal ini menunjukkan bahwa persen hasil yang didapatkan pada penelitian ini yang menggunakan RSM lebih tinggi daripada persen hasil yang didapatkan pada penelitian [9] yang menggunakan metode one variable at time yaitu $60,07 \%$.

\section{KESIMPULAN}

Response Surface Methodology dengan pemilihan model quadratic telah berhasil digunakan untuk mengamati interaksi antar variabel dan menghasilkan suatu solusi kondisi optimum untuk mensintesis asam lemak etanolamida berbasis minyak ketapang. Model yang diperoleh dapat digunakan untuk melihat hasil prediksi sintesis asam lemak etanolamida yang dilakukan. Data perbandingan nilai prediksi dan aktual pada penelitian ini menunjukkan korelasi yang baik dengan melihat persen hasil yang diperoleh secara berturut-turut yaitu 60,02 dan $64,00 \%$.

\section{UCAPAN TERIMA KASIH}

Terima kasih kepada Direktorat Jenderal Pendidikan Tinggi (Dikti) atas sokongan dana penelitian melalui skim Penelitian Dasar Unggulan Perguruan Tinggi (PDUPT) 2019 dan Lembaga Penelitian dan Pengabdian Kepada Masyarakat (LPPM) Universitas Mataram.

\section{DAFTAR PUSTAKA}

[1] Lubis F.S (2018). Karakteristik Senyawa Alkanolamida dari Minyak Jarak Castor dan Dietanolamine dengan Katalis KOH. Jurnal Konversi, 7(2), 31-36.

[2] Guenic, L.C., Vincent, L., Nicolas, J., Patrick, M. and Sarah, L. (2018). Renewable Surfactants for Biochemical Applications and Nanotechnology. Journal of Surfactants and Detergents.

[3] Saleh, F.H.M., Jumail, A.D.C., Muhajirin, F. (2016). Pembuatan Surfaktan Sodium Ligno
Sulfonat dari Ampas Tebu. Teknoin, 22(2), 01-04.

[4] Wuryaningsih. (2006). Kebutuhan akan Penggunaan Surfaktan di Indonesia. Puslit Kimia Lembaga Ilmu Pengetahuan Indonesia (LIPI), Jakarta.

[5] Oppusunngu, J.R., Vinta, R.S., Zuhrina, M. (2015). Pengaruh Jenis Pelarut dan Temperatur Reaksi pada Sintesis Surfaktan dari Asam Oleat dan n-Metil Glukamina dengan Katalis Kimia. Jurnal Teknik Kimia USU, 4(1), 25-29.

[6] Sana, A.W., Zubaidi. (2017). Aplikasi Surfaktan Minyak Sawit Untuk Proses Pemasakan Pengelatangan dan Pencelupan Tekstil. Arena Tekstil, 32(1), 41-50.

[7] Meizar, D.V., Suryani, A., Hambali, E., (2017). Sintesis Surfaktan Dietanolamida (DEA) dari Metil Ester Olein Sawit Menggunakan Reaktor 25 Liter. Jurnal Teknologi Industri Pertanian, 27(3), 328-335.

[8] Anthony, J., dan O'Lenick, J. (2014). Surfactants: Strategic Personal Care. USA, Allured Publishing.

[9] Maag H. (1984). fatty acid derivates : Important Surfactant for Household, Cosmetics and Industrial Purposes, Journal of the American Oil Chemist's Society.

[10] Gunawan, E.R., Suhendra, D., Trisnasari., dan Kurniawati, L. (2018). Optimization of The Enzymatic Ammonolysis of Alkanolamide from Ketapang Karnel Oil. Journal of Physics: Conference Series, 1095(012014).

[11] Putri, N.P., Marjenah., J.G.S. (2018). Ekstraksi Biji Ketapang (Terminalia catappa Linn) Sebagai Bahan Baku Pembuatan Biodiesel. Konversi, 7(1), 10-14.

[12] Gunawan, E.R., Suhendra, D., Windari, B.A. N., Kurniawati, L. (2019). Enzymatic Synthesis of Palmitoylethanolamide from Ketapang Kernel Oil. Journal of Physic, doi:10.1088/1742-6596/1321/2/022034.

[13] Janporn, S., Ho, C.T., Chavasit, V., Pan, M. H., Chittarakorn, S., Ruttarattanamongkol, K., and., Weerawatanakorn, M. (2015). Physicochemical Properties of Terminalia 
Catappa Seed Oil as A Novel Dietary Lipid Source. J Food Drug Anal, 23(2), 201-209.

[14] Ravensca, I., Saleh, C. dan Daniel. (2017). Pembuatan Surfaktan Berbahan Dasar Minyak Biji Ketapang Terminalia catappa L. Dengan Trietanolamina,.Jurnal Atomik, 2(2), 183-189.

[15] Bal, Manisha., Subrata, B., Sushanta, K.B. and Meikapa, B.C. (2018). Modeling and Optimization of Process Variables For $\mathrm{HCl}$ Gas Removal by Response Surface Methodology. Journal of Environmental Science and Health, Doi: 10.1080/10934529.2018.1551650.

[16] Adiansyah, M., Hendrawan, Y., Sumarlan, S.H. (2018). Pemodelan dan Optimasi Proses Biofikasi Karbomdioksida pada Biogas Menggunakan Java Moss dengan Response Surface Methodology. Jurnal Keteknikan Pertanian Tropis dan Biosistem, 6(1), 1-8.

[17] Suhendra, D., Gunawan, E.R dan Hajidi. (2019). Synthesis and Characterization of NMethyl Fatty Hydroxamic Acids from Ketapang Seed Oil Catalyzaed by Lipase. Molecules, 3895(24), 1-7.

[18] Hardiana A. (2019). Optimasi Sintesis Asam Lemak Hidroksamik dari Minyak Inti Biji Ketapang (Terminalia cattapa L.) Secara Enzimatis Menggunakan Response Surface Methodology. Skripsi, Mataram, FMIPA Universitas Mataram.

[19] Pedersen, D.S., Giovanni, D., Ikhsan. (2001), Dry Column Vaccuum Chromatography. Georg Theime Verlag Stuttgart, 30(16), 3234.

[20] Gunawan, E.R., dan Suhendra, D. (2008). Four Factor Response Surface Optimatization of The Enzymatic Synthesis of Wax Ester From Palm Karnel Oil. Indo.J.Chem, 8(1), 8390.
[21] Puspitasari, F. (2013). Analisis Pengaruh Kualitas Layanan Inti dan Kualitas Layanan Peripheral terhadap Kepuasan Nasabah. 10(2), 152-159.

[22] Zhoa, Q., Kennedy, J.F. and Wang, X. (2011). Optimization of Ultrasonic Circulating Extraction of Polysaccarides from Asparagus Officinalis Using Response Surface Methodology. International Journal of Biological Macromolecules, 49, 181-187.

[23] Salamah, S. (2014). Kinetika Reaksi Esterifikasi Minyak Biji Kapuk pada Pembuatan Biodiesel. Chemica, 1(1), 11-18.

[24] Hidayat, C., Danu, M.P., Kuntoro, P.H., Djajeng, S. dan Tatang, H. (2008). Optimasi Sintesis Metil Oleat Menggunakan Biokatalis Lipase dari Kecambah Biji Jatropha curcas L. Jurnal Pascapanen, 5(2), 1-9.

[25] Suhendra, D., Wan, W.M.Z., Md, J.Y., Mahiran, B. dan Sidik, S. (2005). Enzymatic Synthesis of Fatty Hydroxamic Acids from Palm Oil. Journal of Oleo Science, 54(1), 3338.

[26] Worthington, V. (2010). Introduction to Enzymes, New Jersey. Worthington Biochemical Corporation.

[27] Poedjiadi, A. dan Supriyanti, T. (2008). Dasar-dasar Biokimia, Jakarta, UI Press.

[28] Islam, M.E., Parveev, K., Hossain, S. dan Khatun. (2009). Purification and Biochemical Characterization of Lipase From The Dorsal Part of Cirrhimus Reb. Thai Journal of Agricultural Science, 60(6), 281-286.

[29] Iswari, S. (2006). Biokimia, Jakarta: Graha Ilmu.

[30] Gunawan, E.R. dan Suhendra, D. (2011). Enzym-Catalyzed Synthesis of Palm Based Wax-Ester a Kinetic Study. Jurnal Natur Indonesia, 14(1). 